\title{
Former Communist party membership and present-day entrepreneurship
}

\author{
Artjoms Ivlevs • Milena Nikolova • Olga Popova
}

Accepted: 15 May 2020 / Published online: 25 June 2020

(C) The Author(s) 2020

\begin{abstract}
After the collapse of communism in Central and Eastern Europe, former party members were particularly likely to start businesses and become entrepreneurs. What remains unclear, however, is whether this entrepreneurial activity was driven by the resources, information, and opportunities provided by former party membership or because individuals with specific individual attributes were more likely to become Communist cadres (self-selection). This study is the first to separate the causal effect of former Communist party membership from self-
\end{abstract}

Electronic supplementary material The online version of this article (https://doi.org/10.1007/s11187-020-00364-6) contains supplementary material, which is available to authorized users.

A. Ivlevs

Bristol Business School, University of the West of England (UWE Bristol), Frenchay Campus, Coldharbour Lane, Bristol BS16 1QY, UK

A. Ivlevs $(\bowtie) \cdot$ M. Nikolova

Institute of Labor Economics (IZA), Bonn, Germany

e-mail: a.ivlevs@uwe.ac.uk

M. Nikolova

e-mail: m.v.nikolova@rug.nl

\section{Nikolova}

Faculty of Economics and Business, Global Economics and

Management, University of Groningen, Nettelbosje 2, 9747

AE Groningen, The Netherlands selection. Using individual-level Life in TransitionIII survey data and a control function approach, we find that former Communist party membership has facilitated business set-up but not business longevity in Central and Eastern European countries. We also show that people who joined the former ruling party had fewer of the traits associated with entrepreneurship such as unobservable personality traits, ability, motivation, and entrepreneurial aptitude, and as such were negatively self-selected. We show that former Communist party membership still matters for

M. Nikolova

The Brookings Institution, Washington, DC, USA

M. Nikolova $\cdot$ O. Popova

Leibniz Institute for East and Southeast European Studies (IOS), Landshuter Str. 4, 93047 Regensburg, Germany

O. Popova

e-mail: popova@ios-regensburg.de

O. Popova

CERGE-EI, a joint workplace of Charles University and the Economics Institute of the Czech Academy of Sciences, Prague, Czech Republic

O. Popova

Graduate School of Economics and Management, Ural Federal University, Yekaterinburg, Russian Federation 
business practices, business ethics, and the nature of doing business in transition economies.

Keywords Entrepreneurship - Communist party · Elite networks · Post-socialist countries $\cdot$ Central and Eastern Europe

JEL classification L26 $\cdot$ P20 $\cdot$ P31

\section{Introduction}

The communist regimes of Central and Eastern Europe (CEE) typically forbade private enterprise as it was incompatible with the principles of top-down command economies. Because they severely restricted private property and market exchange, and considered state reliance and conformity more ethical and moral than individualism and self-initiative, former communist states created both institutional and cultural obstacles to entrepreneurship (Estrin and Mickiewicz 2011; Neimanis 1997; Ovaska and Sobel 2005).

Vibrant entrepreneurial activity is a key indicator of the success of the marketization and democratization processes in CEE (Bateman 2000; Ovaska and Sobel 2005). Yet progress towards an advanced entrepreneurial society across the region has been uneven (Sauka and Chepurenko 2017). To this day, the negative legacy of communism is still evident in the low entrepreneurship levels, higher fear of failure, and low cultural acceptance of entrepreneurship in CEE compared to other parts of the world (Sauka and Chepurenko 2017; Szerb and Trumbull 2016). Both sub-par economic and political institutions in some of these countries and the historical legacy of communism that discouraged private initiative have been barriers to entrepreneurship in CEE (Aidis and Adachi 2007; Estrin et al. 2006; Estrin and Mickiewicz 2011; McMillan and Woodruff 2002). The business environment in some CEE countries tends to be bureaucratic, highly corrupt, and dysfunctional, which creates multiple hurdles to doing business, such as raising the administrative costs of setting up and operating a business. Unsurprisingly, perceptions of administrative complexities hinder entrepreneurship in CEE (van der Zwan et al. 2011). Given that entrepreneurship improves human welfare through contributing to economic growth, innovation, job creation, and even well-being and health (Kritikos 2014; Nikolova 2019; van Praag and Versloot 2007), studying the causes of entrepreneurial activity is instrumental to promoting social welfare in CEE (Berkowitz and DeJong 2005; Campos and Coricelli 2002).

Despite extensive anecdotal evidence that people with links to the former Communist party were particularly likely to become entrepreneurs when the regime changed (Karpov 2017; Kotz and Weir 2007, p.113; Shapiro 1991), the academic literature on whether and how past experiences with communism and former Communist party membership matter for present-day entrepreneurship in CEE and the FSU regions is scarce. While a handful of empirical studies find that former party links matter for entrepreneurship in CEE and the FSU (Aidis et al. 2008; Djankov et al. 2005; Nikolova and Simroth 2015; Rona-Tas 1994), they fail to clarify what drives the association between former party links and presentday entrepreneurship: whether it is the persistent access to resources, information and opportunities provided by the party networks, or the possibility that people with different unobservable traits, such as motivation, ability, or entrepreneurial aptitude, were more likely to become party members in the first place and subsequently entrepreneurs (self-selection). The objective of our study is to shed light on the mechanisms through which association with the former ruling elite matters for entrepreneurship today. We do so by separating the causal effect of former Communist party membership from that of self-selection. Specifically, using a large householdlevel dataset from the Life in Transition-III survey, we rely on a control function approach that allows us to distinguish between the role of former party membership and self-selection for entrepreneurial outcomes in CEE, 25 years after the fall of communism.

We contribute to and substantially extend two main strands of literature in economics and business. First, and most importantly, we add to the scarce empirical literature on the determinants of the individual entrepreneurship decision in CEE (Aidis et al. 2008; Djankov et al. 2005; Nikolova and Simroth 2015), by focusing on the role of political connections as proxied by former Communist party membership. Specifically, we are the first to offer a causal estimate of the relationship using a representative sample of transition economies, rather than 
Russia, as in seminal papers by Aidis et al. (2008) and Djankov et al. (2005). ${ }^{1}$ In addition, the availability of the entrepreneurship module in the 2016 Life in Transition (LiTS) survey allows us to distinguish between entrepreneurial trial, failure, and success, which is a unique feature of our research. We find that former Communist party membership has facilitated business set-up but not business longevity. Our results also suggest that people with unobservable traits linked to entrepreneurship, such as motivation and entrepreneurial ability, were less likely to join the former ruling party.

Second, and more broadly, we add to the growing literature on the medium- and long-term consequences of socialism and the former Communist party on socioeconomic outcomes, such as education, corruption, and trust (Alesina and Fuchs-Schündeln 2007; Ivlevs and Hinks 2018; Lippmann and Senik 2018; Nikolova et al. 2019; Rainer and Siedler 2009). Specifically, we show that 25 years after the fall of socialist regimes, personal and family links to the former Communist party still matter to entrepreneurship.

\section{Conceptual framework and related literature}

We outline three channels through which former Communist party links may still influence individual entrepreneurial outcomes today: the legacy of communism, social capital, and labor market discrimination.

First, the communist regimes generally thwarted private enterprise and self-initiative, which are conducive to entrepreneurship (Aidis et al. 2008; Estrin et al. 2006; Neimanis 1997). Therefore, people exposed to communism were generally less likely to develop entrepreneurial skills and less able to start and successfully run businesses after the regime change (Tyson et al. 1994). Nevertheless, in many countries, the regime tolerated some unlicensed entrepreneurial activities related to the private use of state machinery or raw materials for small-scale private commercial activities (Dallago

\footnotetext{
${ }^{1}$ The control function analysis includes the following countries: Poland, Czech Republic, Slovakia, Hungary, Romania, Bulgaria, Albania, the seven successor states of Yugoslavia (Bosnia and Herzegovina, Croatia, Former Yugoslav Republic of Macedonia, Kosovo, Montenegro, Slovenia, and Serbia), the Baltic States (Estonia, Latvia, and Lithuania), and Moldova. The first part of the paper shows results using all transition economies, including the former USSR. The LiTS-III did not poll Turkmenistan.
}

2017; Smallbone and Welter 2001). In state-owned enterprises, it was necessary to engage in illegal activities to circumvent the shortages of the planned economy or to engage in bribing and corruption. Procuring materials and equipment was difficult amidst the shortages of the planned economy, and managers, who were often Communist cadres, engaged in these activities themselves to avoid disrupting the production process (Dallago 2017). For instance, the system of elite exchange of mutual favors to tackle shortages and circumvent formal procedures during communism-blatwas fundamental for entrepreneurial activities in transition (Aidis et al. 2008; Ledeneva 1998; Smallbone and Welter 2001). Moreover, communist elites had access to foreign currency with which they paid for shortage of goods. This facilitated their access to black and gray markets (Matthews 2011). Furthermore, Aidis and Adachi (2007) document that "friendly ties" with the local authorities are important complements or substitutes to bribing to ensure business success in Russia. Therefore, paradoxically, dealing with the shortages of the planned economy allowed these former Communist cadres to develop the entrepreneurial and problemsolving skills needed to create and manage their own companies and deal with competition. From this perspective, people with former Communist party links may be more likely to have started a business and succeeded in running one.

Second, the network of former Communist cadres provided political, social, and financial capital and guarded against malfunctioning political and economic institutions. Political control of economic activity, often by the same former Communist elites, continued throughout the transition process (Johnson et al. 1997; Pakulski et al. 1996). Shortly after the regime change, managers of former state-owned enterprises and those close to politics privatized these businesses by purchasing them at low prices (Estrin et al. 2009; Hamm et al. 2012; Shelley 1992; Stoica 2004). As such, those with connections to the Communist party typically got a head start and became "nomenclatura entrepreneurs" (Estrin et al. 2006; Filatotchev et al. 1994; Smallbone and Welter 2001). However, business managers with a former Communist party membership background are less aggressive competitors than those without party associations, meaning that former Communists are less likely to be engaged in consumer fraud or predatory pricing (Brouthers et al. 2008; Neimanis 1997). This can be explained by their higher risk aversion developed under 
the communist ideology and their desire to maintain the status quo and their own benefits (Neimanis 1997). This suggests that despite being successful in the set-up phase, former Communist party members may be less successful in maintaining their business in the long-run, as compared to those without former party affiliation.

Furthermore, former Communist party membership matters for current entrepreneurial outcomes through guarding against dysfunctional institutions, which are still notable in some transition economies. Given the weak enforcement of property rights, business networks and trust-based informal institutions may substitute for the formal rule of law (Granovetter 1985; Nooteboom 2007; Smallbone and Welter 2001). Such networks could also protect their members against extortion from the mafia or local authorities, destruction of their physical capital, and the lack of enforcement of contracts (Berkowitz and DeJong 2005).

In addition, former ruling party networks may create entry barriers for outsiders, thus assisting regime insiders in securing their position. Therefore, those without connections may be at a disadvantage when starting and maintaining a business, because they may be vulnerable to economic and political insecurity and extortion from public officials or the criminal world (Aidis et al. 2008).

The final channel through which former cadres and their descendants may be relatively more likely to start their own businesses relates to labor market discrimination. In some former communist countries, such as Latvia, Czechoslovakia, East Germany, and Poland, people linked to the former ruling regime (for example, former Communist party members and secret regime informants) were barred from running for political office or holding public administration posts (Euractiv 2002; Szczerbiak 2002; Welsh 1996). Facing no career prospects for high-level political jobs, a scarcity of jobs in the private sector, and possible stigma attached to being affiliated with the former ruling regime, Communist cadres may have had little choice but to become entrepreneurs.

To our knowledge, no papers on former Communist party membership and present-day entrepreneurship in CEE theoretically and empirically distinguish between self-selection and social network channels. A priori, discerning the direction of the selection bias is nontrivial. On the one hand, the Communist party granted membership to the most able and ambitious individuals (Geishecker and Haisken-DeNew 2004; Gershenson and Grossman 2001), which are characteristics linked with entrepreneurial talent. On the other hand, the Communist party selected members who were loyal and obedient, which are traits that are less conducive to entrepreneurship. Our main contribution to the literature is that we clearly distinguish between selection and the benefits of party membership as such.

Our paper most closely relates to, yet fundamentally differs from, the contribution by Aidis et al. (2008), which examines how the institutional environment and current business ownership matter for entrepreneurial development in Russia. The authors find that knowing entrepreneurs and being a current business owner increase the likelihood of starting a new business in Russia, which points to the embeddedness of entrepreneurial networks. ${ }^{2}$ While we build on the insights in Aidis et al. (2008), we differ in that we do not focus on Russia but rather on the CEE region. Furthermore, we use a different proxy for entrepreneurial networks (former Communist party membership), and most importantly, we provide causal estimates rather than conditional correlations.

We also acknowledge two related papers. First, Djankov et al. (2005) show that parental former Communist party membership is not robustly associated with business start-ups and longevity in Russia. Meanwhile, parental education and having entrepreneurial friends and family are positively associated with being an entrepreneur. Second, in a contribution examining the role of religious diversity and entrepreneurship in CEE and Central Asia, Nikolova and Simroth (2015) use former Communist party membership as a control variable and find that former Communist party ties are positively associated with entrepreneurial trials, but not with successful business set-up. Nikolova and Simroth (2015) only mention the Communist party finding in passing, do not explore the channels and mechanisms behind the relationship, and provide only cross-sectional insights. Importantly, because they rely on an earlier data wave that did not have the entrepreneurship module, Nikolova and Simroth (2015) only examine the probability of being self-employed. By contrast, we examine several stages of the business venture creation and survival process.

\footnotetext{
${ }^{2}$ Based on the 1993 survey of individuals in six CEE countries, Earle and Sakova (1999) find that the probability of being self-employed is uncorrelated with former Communist party membership, but with individual education, family wealth, and pre-communist family business holding.
} 


\section{Data, variables, and estimation strategy}

3.1 Data

We use cross-sectional nationally representative data from the Life in Transition-III survey (LiTS-III), ${ }^{3}$ collected by the European Bank of Reconstruction and Development and the World Bank in 2015/2016. The survey covered 29 post-socialist countries of CEE and Central Asia (including Mongolia), as well as Turkey, Greece, Cyprus, Germany, and Italy. Information on former Communist party membership was only collected in post-socialist states. The survey excluded Turkmenistan.

In each country, the LiTS-III conducted 1500 faceto-face interviews. Households were selected according to a two-stage clustered stratified sampling procedure. In the first stage, the frame of primary sampling units was established using information on local electoral territorial units. In the second stage, a random walk fieldwork procedure was used to select households within primary sampling units. Further information about the survey design and implementation are available in the LiTS Annex (EBRD 2016).

\subsection{Variables}

\subsubsection{Outcome variable: entrepreneurial activity}

A unique feature of the LiTS-III is that it contains detailed information on respondents' past and present entrepreneurial activities. Our dependent variable (started business) is based on responses to the question "Have you ever tried to set up a business?," with possible answers "Yes, I have set up my current business," "Yes, I set up a business in the past but I am no longer involved in it or it is no longer operational," "Yes. I tried to set up a business and did not succeed (in setting it up)," and "No."

\footnotetext{
3 The two previous waves of this (repeated cross-sectional) survey were conducted in 2006 (Life in Transition-I) and 2010 (Life in Transition-II). We chose the latest (2015/2016) wave for our study, as we wanted to see the effects of former Communist party membership over the longest possible time horizon. Also, a set of detailed questions on entrepreneurial activity as well as the geolocation of respondents were only available in the third wave of the survey.
}

3.2.2 Main explanatory variable: former communist party membership

Our key independent variable captures connections with the former Communist party based on whether respondents themselves, their parents, or other family members were party members prior to $1989 / 1991 .^{4}$ First, the variable any personal or family link to the former Communist party takes value 1 when the respondent has a personal or family connection with the former Communist party and 0 otherwise. Next, we created three separate dichotomous variables measuring the following: (i) individuals who themselves were party members; (ii) the children of former party members; and (iii) the relatives (other than children) of former party members. These categories can overlap because the respondent can be a former party member themselves and at the same time have parents or relatives who were also party members. About $21 \%$ of respondents in our analysis sample report links to the former Communist party, ranging from $39 \%$ in Montenegro to $12 \%$ in Hungary.

\subsubsection{Control variables}

Our regressions include standard control variables used in the entrepreneurship literature (e.g., Aidis et al. 2008; Block et al. 2015; Demirgüç-Kunt et al. 2007; Djankov et al. 2005; Estrin et al. 2013a, b; Nikolova and Simroth 2015). Specifically, we add to our regressions three sets of control variables. First, the set of individual- and household-level controls consists of the respondent's gender, age and its square, ethnic minority status, religious affiliation, retirement and disability status, respondent's height, respondent's education, a wealth index based on information about household assets, employment status, marital status, household size, number of children under 18, subjective health assessment, risk attitudes, current membership of any political party, parental education, and the number of books at home during the respondent's childhood. Second, the set of geography-related controls consists of the urbanity status (capital, urban-not-capital, rural), latitude, longitude, and elevation of the respondent's place of residence. Finally, to account for all possible country-level influences and capture within-country relationships between

\footnotetext{
${ }^{4}$ The Soviet Union broke down in 1991, while in most satellite countries of Eastern Europe the communist regimes fell in 1989-1990.
} 
former Communist party membership and entrepreneurship, we include country-fixed effects. ${ }^{5}$

To avoid bias from dropping observations with missing information, we create an additional category for missing information where the share of missing observations for a particular categorical variable is greater than $1 \%$. The only continuous variable with a share of missing observations higher than $1 \%$ is that of respondents' height (11\% missing observations); here we create within-country height tertiles and treat the variable as categorical with missing observations being the fourth category. The missing category for these variables has no particular interpretation but serves to preserve the number of observations. The summary statistics on all variables used in the analysis is available in Table S1 in the Supplementary Information file. ${ }^{6}$

\subsection{Estimation strategy}

We model the entrepreneurship outcome started busi$n e s s$ of each individual $i$ living in country $j$ as follows:

$$
\begin{aligned}
\text { Started business }_{i j}= & \beta_{0}+\beta_{1} \text { Communist party }_{i j} \\
& +\boldsymbol{X}_{i j}^{\prime} \gamma+\varepsilon_{i j}
\end{aligned}
$$

where Communist party captures personal or familial ties to the former Communist party, $\boldsymbol{X}$ is a vector of control variables described above, and $\varepsilon$ is the stochastic error term. Given the likely interdependence of respondent outcomes at the local level, we cluster the standard errors at the primary sampling unit (PSU) level. Given the categorical and unordered nature of the dependent variable, we rely on a multinomial logit estimator. The underlying assumption of the multinomial logit model is the independence of irrelevant alternatives (IIA), i.e., the assumption that the relative probability of choosing between two options is independent of additional alternatives in

\footnotetext{
${ }^{5}$ For brevity, we only report the tables with the full set of controls but alternative specifications are available upon request.

${ }^{6}$ We have tested for multicollinearity (see Tables S2 and S3). VIFs for the majority of regressors are below 10, suggesting that multicollinearity is not an issue. As expected, VIFs for the age variable and its square are high (44-47). VIFs for lower secondary education, upper secondary education, latitude, and the Estonia dummy are between 10 and 17. A closer inspection reveals that education levels are correlated with own and parental education levels, and latitude is correlated with country dummies (including Estonia). Taking this information into account and given a large sample size, we decided not to exclude/combine any variables.
}

the choice set. We have tested for the IIA assumption and found that in our case it is not violated. ${ }^{7}$

The parameter $\beta_{1}$ captures the association between former Communist party membership and entrepreneurial activity rather than a causal effect. The Communist party variable is potentially endogenous, meaning that $\beta_{1}$ may not reflect the true causal effect of party membership on entrepreneurship but rather self-selection into entrepreneurship across households. For example, individuals living in households with certain family environments, or observed or unobserved characteristics related to motivation or ability, may be more likely to both be or be linked to a former party member and start a business. ${ }^{8}$

To mitigate endogeneity issues and identify causal effects, we employ a control function approach, a technique that is similar to the instrumental variable approach (Petrin and Train 2010; Rivers and Vuong 1988; Wooldridge 2015), and suitable for non-linear models, such as the multinomial logit that we use in our analysis. ${ }^{9}$ Sometimes referred to as a two-stage residual inclusion (2SRI) (Terza et al. 2008), this approach necessitates one or more variables - instruments - that are highly correlated with the endogenous regressor (former Communist party membership) and affect the outcome (entrepreneurship) only through the endogenous regressor. In the first stage, the exogenous variation brought by the instruments also induces variation in the generalized residuals, which serve as control functions (Wooldridge 2015). Including the control functions in the second stage renders the endogenous independent variable (former Communist party membership) plausibly exogenous. The advantage of the control function approach in our case is that it also handles non-linear endogenous variables.

Following Terza et al. (2008), we estimate a firststage auxiliary regression using a generalized linear model, with a binomial family and probit link, whereby the potentially endogenous regressor (i.e., former Communist party membership) is explained by the instruments and all the control variables. Next, we include the

\footnotetext{
${ }^{7}$ To test for IIA, we used the suest Hausman test, which is a part of the user-written command mlogtest in Stata (Long and Freese 2014). The results of the test are provided in Table S4 of Supplementary Information.

${ }^{8}$ While we include a set of control variables that mitigate the endogeneity related to self-selection, we lack important control variables related to parental occupation, which could also result in endogeneity due to omitted variables bias.

${ }^{9}$ Terza et al. (2008) show that in a non-linear model, such as multinomial logit, the standard two-stage least squares estimation will produce inconsistent results.
} 


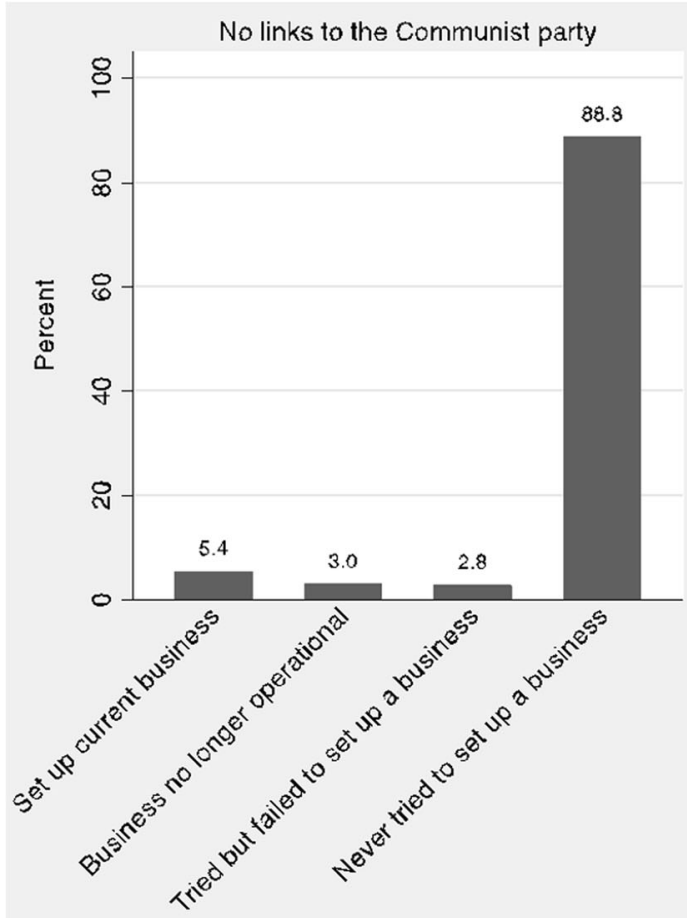

Fig. 1 Distribution of respondents who have set up a business, tried to set up a business, failed to set up a business, and never tried to set up a business, by former Communist party links. Source: Authors' calculations based on data from the LiTS-III. Notes: The figure summarizes the mean of the proportion of responses to the

predicted first-stage residuals, along with the endogenous regressor, in the second stage estimation. The standard errors in the second stage and the reported marginal effects are based on bootstrapped clustered replications. The coefficient estimate on the endogenous regressor in the second stage represents the unbiased effect of the former Communist party on entrepreneurial activity, while that on the predicted residuals captures the endogeneity bias. We estimate the following system of equations:

$1^{\text {st }}$ stage : Communist party ${ }_{i j}$

$$
=\gamma_{0}+\gamma_{1} \text { Instruments }_{i j}+\boldsymbol{X}_{i j}^{\prime} \boldsymbol{\pi}+u_{i j}
$$

$2^{\text {nd }}$ stage : Started business $i j$

$$
\begin{aligned}
= & \widetilde{\beta}_{0}+\widetilde{\beta}_{1} \text { Communist party } \\
& +\boldsymbol{X}_{i j}^{\prime} \widetilde{\gamma}+\zeta_{i j}
\end{aligned}
$$

where, for each individual $i$ in country $j, X$ denotes a vector of all control variables (including country-fixed

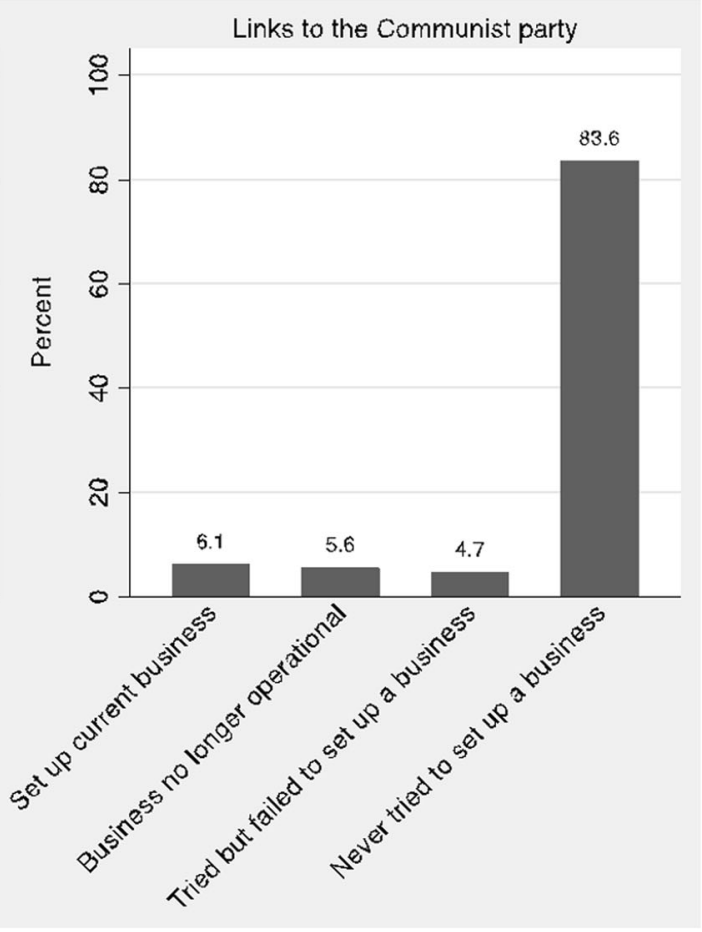

question "Have you ever tried to set up a business?," with possible answers "Yes, I have set up my current business," "Yes, I set up a business in the past but I am no longer involved in it or it is no longer operational," "Yes, I tried to set up a business and did not succeed (in setting it up)," and "No"

effects), $u$ is the error term of the first-stage regression, $u^{\text {est }}$ is the predicted residual from the first-stage equation, and $\zeta$ is the error term in the second-stage regression.

One advantage of the control function approach is that the inclusion of the residuals provides a Hausman test of the null hypothesis that the Communist party variable is exogenous (Bollen et al. 1995; Wooldridge 2015). Specifically, the statistical significance of the coefficient estimate on the predicted residuals, denoted by $\alpha$ in Eq. (3), indicates that the Communist party membership variable is endogenous, implying that the control function rather than simple multinomial regression results should be used for interpretation.

Following Ivlevs and Hinks (2018), we instrument personal and family links to the former Communist party with information about the involvement of respondents' family members in the Second World War (WWII). Ivlevs and Hinks (2018) summarize evidence showing that across the former socialist world, WWII veterans (and in many cases civilians who were affected 
Table 1 Distribution of respondents who have set up a business, tried to set up a business, failed to set up a business, and never tried to set up a business in country groups in the LiTS

\begin{tabular}{|c|c|c|c|c|c|c|c|c|}
\hline & \multicolumn{2}{|c|}{$\begin{array}{l}\text { Business still } \\
\text { active }\end{array}$} & \multicolumn{2}{|c|}{$\begin{array}{l}\text { Business closed } \\
\text { down }\end{array}$} & \multicolumn{2}{|c|}{$\begin{array}{l}\text { Failed at setting up a } \\
\text { business }\end{array}$} & \multicolumn{2}{|c|}{ Never tried } \\
\hline & Mean & Std. dev. & Mean & Std. dev. & Mean & Std. dev. & Mean & Std. dev. \\
\hline All post-socialist countries, $N=42,548$ & 0.055 & 0.229 & 0.035 & 0.185 & 0.032 & 0.176 & 0.877 & 0.328 \\
\hline Former Soviet Union, $N=22,104$ & 0.055 & 0.228 & 0.040 & 0.196 & 0.040 & 0.197 & 0.864 & 0.342 \\
\hline Balkans, $N=14,453$ & 0.055 & 0.229 & 0.027 & 0.162 & 0.024 & 0.153 & 0.894 & 0.308 \\
\hline Visegrad, $N=4463$ & 0.055 & 0.229 & 0.027 & 0.162 & 0.024 & 0.153 & 0.894 & 0.308 \\
\hline Baltics, $N=4464$ & 0.057 & 0.233 & 0.062 & 0.241 & 0.026 & 0.158 & 0.855 & 0.352 \\
\hline Analysis sample in Table $3, N=20,922$ & 0.055 & 0.228 & 0.036 & 0.187 & 0.024 & 0.152 & 0.885 & 0.319 \\
\hline Cyprus, Greece, Germany, Italy, Turkey, $N=7504$ & 0.055 & 0.228 & 0.036 & 0.187 & 0.024 & 0.152 & 0.885 & 0.319 \\
\hline
\end{tabular}

Source: Authors' calculations based on data from the LiTS-III

The table summarizes the mean of the proportion of responses to the question "Have you ever tried to set up a business?," with possible answers "Yes, I have set up my current business," "Yes, I set up a business in the past but I am no longer involved in it or it is no longer operational," "Yes, I tried to set up a business and did not succeed (in setting it up)," and "No." The Balkans sample includes Croatia, Bosnia and Herzegovina, Slovenia, Serbia, Montenegro, Kosovo, Macedonia, Romania, Bulgaria, and Albania. The Visegrad countries are Poland, Slovakia, Czech Republic, and Hungary. The Baltics are Estonia, Latvia, and Lithuania. The former Soviet Union countries are Armenia, Azerbaijan, Belarus, Estonia, Georgia, Kazakhstan, Kyrgyzstan, Latvia, Lithuania, Moldova, Mongolia, Russia, Tajikistan, Ukraine, and Uzbekistan. Turkmenistan is not included in the LiTS-III. The analysis sample in Table 3 group includes Poland, Czech Republic, Slovakia, Hungary, Romania, Bulgaria, Albania, the seven successor states of Yugoslavia (Bosnia and Herzegovina, Croatia, Former Yugoslav Republic of Macedonia, Kosovo, Montenegro, Slovenia, and Serbia), the Baltic States (Estonia, Latvia, and Lithuania), and Moldova

by war) were encouraged and given priority to join the Communist party and take leading positions in the government and various administrative bodies. Our expectation is that people who themselves, or whose parents and grandparents, fought in, or were otherwise affected by, WWII would be more likely to have either personal affiliation or family links to the former Communist party (instrument relevance).
The assumption about instrument exogeneity, that being affected by WWII (or being the descendant of such people) is uncorrelated with the error term, necessitates further discussion. While this assumption is fundamentally untestable, we provide historical arguments about its plausibility. It is unlikely that when WWII started, people joined the army because they thought it would make it easier to join

Table 2 Selected summary statistics, analysis sample

\begin{tabular}{llllll}
\hline & \multicolumn{2}{l}{ No links to the Communist party, $N=16,594$} & & \multicolumn{2}{c}{ Links to the Communist party, $N=4328$} \\
\cline { 2 - 3 } & Mean & Std. dev. & Mean & Std. dev. \\
\hline Age* & 50.284 & 17.772 & 55.665 & 16.449 \\
Male* & 0.441 & 0.497 & 0.465 & 0.499 \\
Tertiary (less than bachelor's degree)* & 0.058 & 0.094 & 0.234 & 0.069 & 0.254 \\
Bachelor's degree* & 0.051 & 0.292 & 0.124 & 0.330 \\
Master's or PhD* & 5.455 & 0.220 & 0.069 & 0.254 \\
Wealth index (scale 1-8)* & 0.072 & 1.699 & 5.461 & 1.670 \\
Had more than 200 books in childhood* & 0.259 & 0.111 & 0.314
\end{tabular}

Source: Authors' calculations based on data from the LiTS-III

*Designates statistically significant difference in means between those with and those without former Communist party membership links at $1 \%$ or lower 
Table 3 Links to the former Communist party and present-day entrepreneurial activity, multinomial logit marginal effects

\begin{tabular}{lllll}
\hline & $\begin{array}{l}\text { Set up current } \\
\text { business } \\
(1)\end{array}$ & $\begin{array}{l}\text { Business no longer } \\
\text { operational } \\
(2)\end{array}$ & $\begin{array}{l}\text { Tried but failed to set up a } \\
\text { business } \\
(3)\end{array}$ & $\begin{array}{l}\text { Never tried to set up a } \\
\text { business } \\
(4)\end{array}$ \\
\hline $\begin{array}{l}\text { Any link to the Communist } \\
\text { party }\end{array}$ & 0.002 & $0.012^{* * *}$ & $0.007^{* * *}$ & $-0.021^{* * *}$ \\
Individual/household-level & $(0.004)$ & $(0.003)$ & $(0.003)$ & Yes \\
$\quad$ Yentrols & Yes & Yes & Yes & Yes \\
$\begin{array}{l}\text { Geography controls } \\
\text { Country-fixed effects }\end{array}$ & Yes & Yes & Yes & Yes \\
Observations & 20,922 & & & \\
Wald $\chi^{2}$ & 2838.290 & & & \\
Prob $>\chi^{2}$ & 0.000 & & & \\
Pseudo $R^{2}$ & 0.144 & & &
\end{tabular}

Source: Authors' calculations based on data from the LiTS-III

Standard errors, clustered at the primary sampling unit level, in parentheses. $* * * p<0.01, * * p<0.05, * p<0.1$

Individual/household-level controls include gender, age and its square, ethnic minority status, religious affiliation, being retired, being disabled, height, education level, wealth index, employment status, marital status, household size, number of children under 18, subjective health assessment, risk attitudes, membership of (any) political party, parental education, and the number of books at home during the respondent's childhood. Geography controls include the urbanity status (capital, urban-not-capital, rural), latitude, longitude, and elevation of the respondent's place of residence. See Supplementary Information for complete econometric output

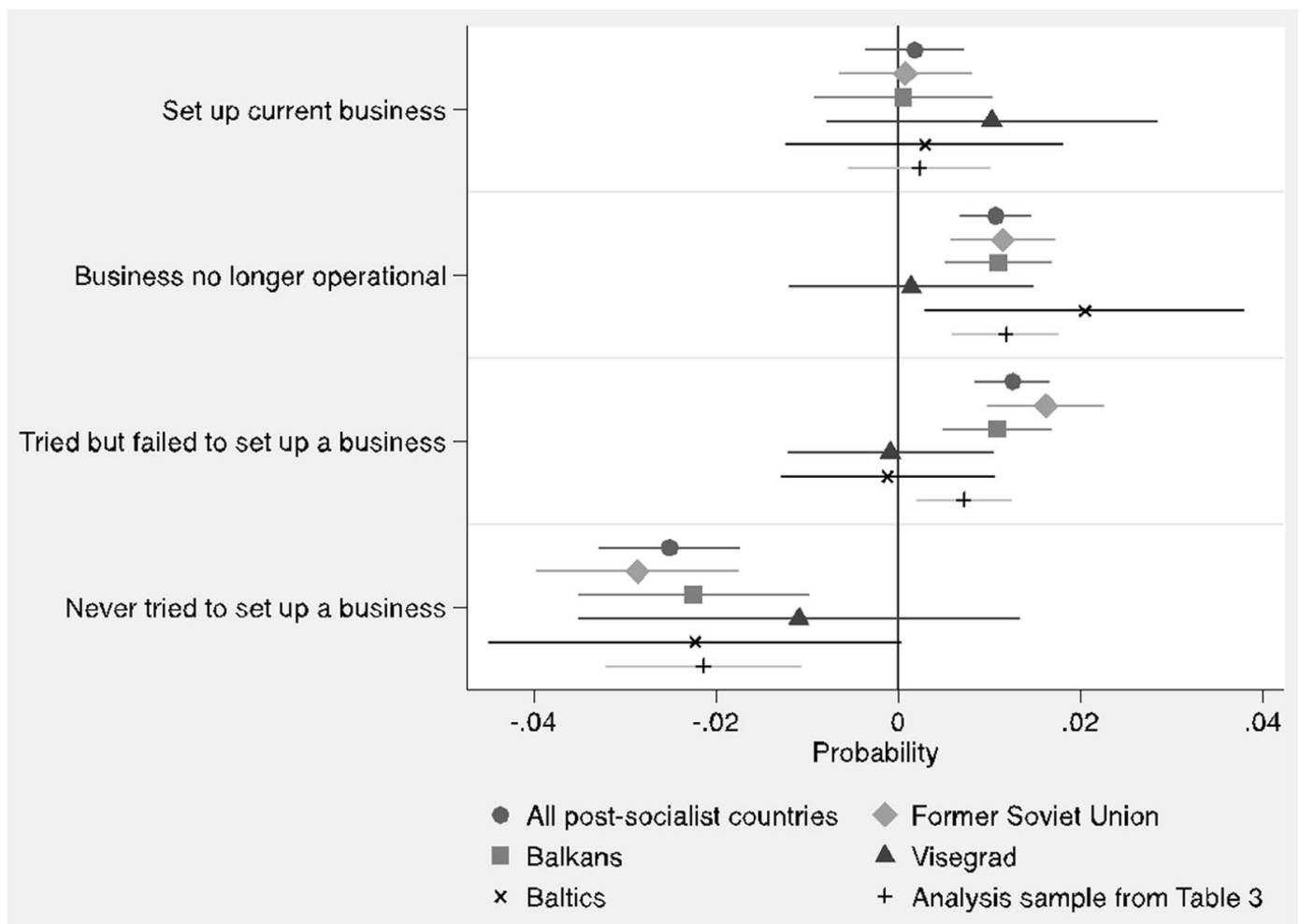

Fig. 2 Links to the former Communist party and present-day entrepreneurial activity, multinomial logit marginal effects. Source: Authors' calculations based on data from the LiTS-III. Notes: The figure shows the effect of former Communist party membership on the predicted probability of each value of the outcome variable. The reported coefficient estimates are reported as marginal effects based on multinomial logistic regressions with standard errors clustered at the primary sampling unit level. See Table 2 notes for the list of individual and geography controls included in the regressions and Table 1 notes for the composition of country groups. Complete econometric output, on which the graph is based, is available on request 
the ruling party during or after the war which, in turn, would help them to establish businesses after a regime change. However, some people might have wished to go to war in anticipation of joining the party and benefiting from the advantages that party membership brings (for example, be in power/ managerial positions and exploit advantageous networks). If the personal characteristics of such individuals are linked with traits that determine the likelihood and success of entrepreneurial activities (Caliendo et al. 2014), the instruments may not be exogenous. To ensure that these considerations pose no threat to our instrument's validity, following Ivlevs and Hinks (2018), we concentrate on the CEE countries that did not have communist regimes before WWII. This allows us to rule out the possibility that people in these countries joined the war effort in order to become members of the Communist party during or after the war. There are 18 such countries in our sample-Poland, Czech Republic, Slovakia, Hungary, Romania, Bulgaria, Albania, the seven successor states of Yugoslavia (Bosnia and Herzegovina, Croatia, Former Yugoslav Republic of Macedonia, Kosovo, Montenegro, Slovenia, and Serbia), the Baltic States (Estonia, Latvia, and Lithuania), and Moldova. ${ }^{10}$ Our analysis sample therefore only includes this set of countries.

We measure respondents', their parents', and grandparents' involvement in WWII using information from two survey questions: (i) "Were you, your parents or any of your grandparents physically injured or were your parents or any of your grandparents killed during WWII?" and (ii) "Did you, your parents or any of your grandparents have to move as a result of WWII?," with possible answers "Yes" and "No." We construct two binary variables, killed/ injured in WWII and displaced as a result of $W W I I,{ }^{11}$ and expect both to be positively correlated with personal or family links to the former

\footnotetext{
${ }^{10}$ We include the three Baltic States and Moldova as they had very short exposure (1 year) to communist rule before WWII started. Our results are unchanged if these four countries are excluded from the analysis. However, as the three Baltic States and Moldova witnessed high levels of state-managed immigration from other USSR republics, predominantly Russia, Belarus, and Ukraine, we exclude from the analysis respondents of Russian, Belorussian, and Ukrainian ethnic origin.

${ }^{11}$ Importantly, $15 \%$ of respondents provided no answers to these questions and are excluded from the analysis.
}

Communist party. We note that apart from fighting in WWII, these variables would also capture broader WWII effects on civilians. However, in many cases - for example, relocation to a labor camp or participating in an underground resistance movement - civilians affected by WWII would also receive preferential treatment after the war.

\section{Results}

\subsection{Summary statistics}

Figure 1 and Table 1 below demonstrate that overall, about $5.5 \%$ of respondents are current business owners, $3.6 \%$ started a business that subsequently closed down, $2.6 \%$ failed at starting a business, and about $88 \%$ were never involved in a start-up. These statistics are similar across the group of post-socialist countries and also comparable to the figures for the non-transition countries in the LiTS-III (Cyprus, Greece, Germany, Italy, Turkey, $N=7504$ ) (Table 1).

Table 2 further demonstrates differences in the characteristics of respondents with and without links to the former Communist party. Specifically, those with former ruling party ties tend to be older, are more likely to be male, more educated, and to have grown up in a home with more than 200 books. We expect that these differences matter for the selection of households into entrepreneurship based on former political connections.

Figure 1 offers the first glimpse into differences in entrepreneurship outcomes according to former Communist party membership. Evidently, those connected to the former ruling elites are more likely to have tried and succeeded in setting up a business than individuals without such connections. Nevertheless, in subsequent analyses, we test whether these raw differences withstand robust econometric analyses.

\subsection{Main results}

Table 3 reports the results of the multinomial logit model without accounting for the endogeneity of the Communist party variable. For brevity, we only report the marginal effects of the focal regressors; complete econometric output, including the raw multinomial logit coefficients and a commentary on the control variables, 
Table 4 Links to the former Communist party and present-day entrepreneurial activity, instrumental variable results

\begin{tabular}{|c|c|c|c|c|c|}
\hline & \multirow{2}{*}{$\begin{array}{l}\text { 1st stage } \\
\text { Any link to the } \\
\text { Communist party } \\
\text { (1) }\end{array}$} & \multicolumn{4}{|c|}{$\begin{array}{l}\text { 2nd stage } \\
\text { Dependent variable }- \text { started business }\end{array}$} \\
\hline & & $\begin{array}{l}\text { Set up current } \\
\text { business } \\
\text { (2) }\end{array}$ & $\begin{array}{l}\text { Business no longer } \\
\text { operational } \\
\text { (3) }\end{array}$ & $\begin{array}{l}\text { Tried but failed to set } \\
\text { up a business } \\
\text { (4) }\end{array}$ & $\begin{array}{l}\text { Never tried to set up } \\
\text { a business } \\
\text { (5) }\end{array}$ \\
\hline $\begin{array}{l}\text { Any link to the Communist } \\
\text { party }\end{array}$ & - & $\begin{array}{l}0.047 \\
(0.031)\end{array}$ & $\begin{array}{l}0.077 * * * \\
(0.021)\end{array}$ & $\begin{array}{l}0.063 * * * \\
(0.013)\end{array}$ & $\begin{array}{l}-0.187 * * * \\
(0.027)\end{array}$ \\
\hline 1st stage predicted residuals & - & $\begin{array}{l}-0.045 \\
(0.031)\end{array}$ & $\begin{array}{l}-0.066^{* * * *} \\
(0.021)\end{array}$ & $\begin{array}{l}-0.057 * * * \\
(0.014)\end{array}$ & $\begin{array}{l}0.170 * * * \\
(0.025)\end{array}$ \\
\hline $\begin{array}{l}\text { Individual/household-level } \\
\text { controls }\end{array}$ & Yes & Yes & Yes & Yes & Yes \\
\hline Geography-related controls & Yes & Yes & Yes & Yes & Yes \\
\hline Country-fixed effects & Yes & Yes & Yes & Yes & Yes \\
\hline $\begin{array}{l}\text { Family member } \\
\text { killed/injured in WWII }\end{array}$ & $\begin{array}{l}0.085 * * * \\
(0.008)\end{array}$ & - & - & - & - \\
\hline $\begin{array}{l}\text { Family member moved as a } \\
\text { result of WWII }\end{array}$ & $\begin{array}{l}0.061 * * * \\
(0.009)\end{array}$ & - & - & - & - \\
\hline $\begin{array}{l}\text { F-statistic (excluded } \\
\text { instruments) }\end{array}$ & $206.57 * * *$ & & & & \\
\hline Observations & 20,922 & 20,922 & & & \\
\hline AIC/Pseudo $R^{2}$ & 0.916 & 0.146 & & & \\
\hline
\end{tabular}

Source: Authors' calculations based on data from the LiTS-III

Standard errors, clustered at the primary sampling unit level, in parentheses. $* * * p<0.01, * * p<0.05, * p<0.1$. The first stage of the instrumental variable model is estimated with the generalized linear model (GLM) technique, using a binomial family and a probit link and the reported coefficient estimates are average marginal effects. The second stage is estimated with a multinomial logit and this table reports the average marginal effects. The second stage standard errors are bootstrapped. See Table 2 notes for the list of individual and geography controls included in the regressions. Complete econometric output is available on request

is available in the Supplementary Information file (Table S5).

The results in Column (1) of Table 3 suggest that having personal or family links to the former Communist party is a statistically insignificant predictor of having set up and running a business at the time of the interview. Meanwhile, people with former Communist party links are 1.2 percentage points more likely to report that they set up a business in the past but were no longer involved in it or the business was no longer operational (Column (2)), 0.7 percentage points more likely to report that they had tried to set up a business in the past but did not succeed in doing so (Column (3)), and 2.1 percentage points less likely to report that they had never tried to set up a business (Column (4)).

The results presented in Table 3 hold across all postsocialist country contexts. Specifically, we replicated the analyses in Table 3 for the full sample of postsocialist countries in the LiTS-III, as well as for the
Balkans, Baltics, Visegrad, and former Soviet Union countries. Figure 2, which summarizes the results for these country contexts, demonstrates that the relationship between former Communist party membership and entrepreneurship are nearly universal in the transition region. Interestingly, however, former Communist party membership in the Visegrad countries (Poland, Czech Republic, Slovakia, and Hungary) is not associated with entrepreneurial trial and success. Given that some forms of entrepreneurship existed in these countries before the collapse of communism (Dallago 2017), nascent Visegrad entrepreneurs likely relied on their past experiences rather than political connections and informal networks.

Overall, our results imply that people with links to the former Communist party are more likely to report having tried - successfully or unsuccessfully - to set up a business in the past, although they may not necessarily be involved in the business at the time of the interview. This finding holds across the transition region and is not 
Table 5 Personal and family links to the former Communist party and present-day entrepreneurial activity, multinomial logit marginal effects

Set up current business

(1)
Business no longer operational

(2)
Tried but failed to set up a business

(3)
Never tried to set up a business

(4)

\begin{tabular}{|c|c|c|c|c|}
\hline \multirow{2}{*}{$\begin{array}{l}\text { Former Communist party } \\
\text { member }\end{array}$} & 0.012 & $0.014 * * *$ & 0.005 & $-0.031 * * *$ \\
\hline & $(0.008)$ & $(0.005)$ & $(0.005)$ & $(0.010)$ \\
\hline \multirow{2}{*}{$\begin{array}{l}\text { Child of Communist party } \\
\text { member }\end{array}$} & -0.001 & $0.009 * * *$ & 0.004 & $-0.012 *$ \\
\hline & $(0.005)$ & $(0.003)$ & $(0.003)$ & $(0.006)$ \\
\hline \multirow{2}{*}{$\begin{array}{l}\text { Relative of Communist party } \\
\text { member }\end{array}$} & -0.006 & 0.004 & 0.006 & -0.004 \\
\hline & $(0.006)$ & $(0.005)$ & $(0.004)$ & $(0.009)$ \\
\hline $\begin{array}{l}\text { Individual/household-level } \\
\text { controls }\end{array}$ & Yes & Yes & Yes & Yes \\
\hline Geography-related controls & Yes & Yes & Yes & Yes \\
\hline Country-fixed effects & Yes & Yes & Yes & Yes \\
\hline Observations & 20,922 & & & \\
\hline Wald $\chi^{2}$ & 2868.490 & & & \\
\hline Prob $>\chi^{2}$ & 0.000 & & & \\
\hline Pseudo $R^{2}$ & 0.144 & & & \\
\hline
\end{tabular}

Source: Authors' calculations based on data from the LiTS-III

Standard errors, clustered at the primary sampling unit level, in parentheses. $* * * p<0.01, * * p<0.05, * p<0.1$

See Table 2 notes for the list of individual and geography controls included in the regressions. Complete econometric output is available on request
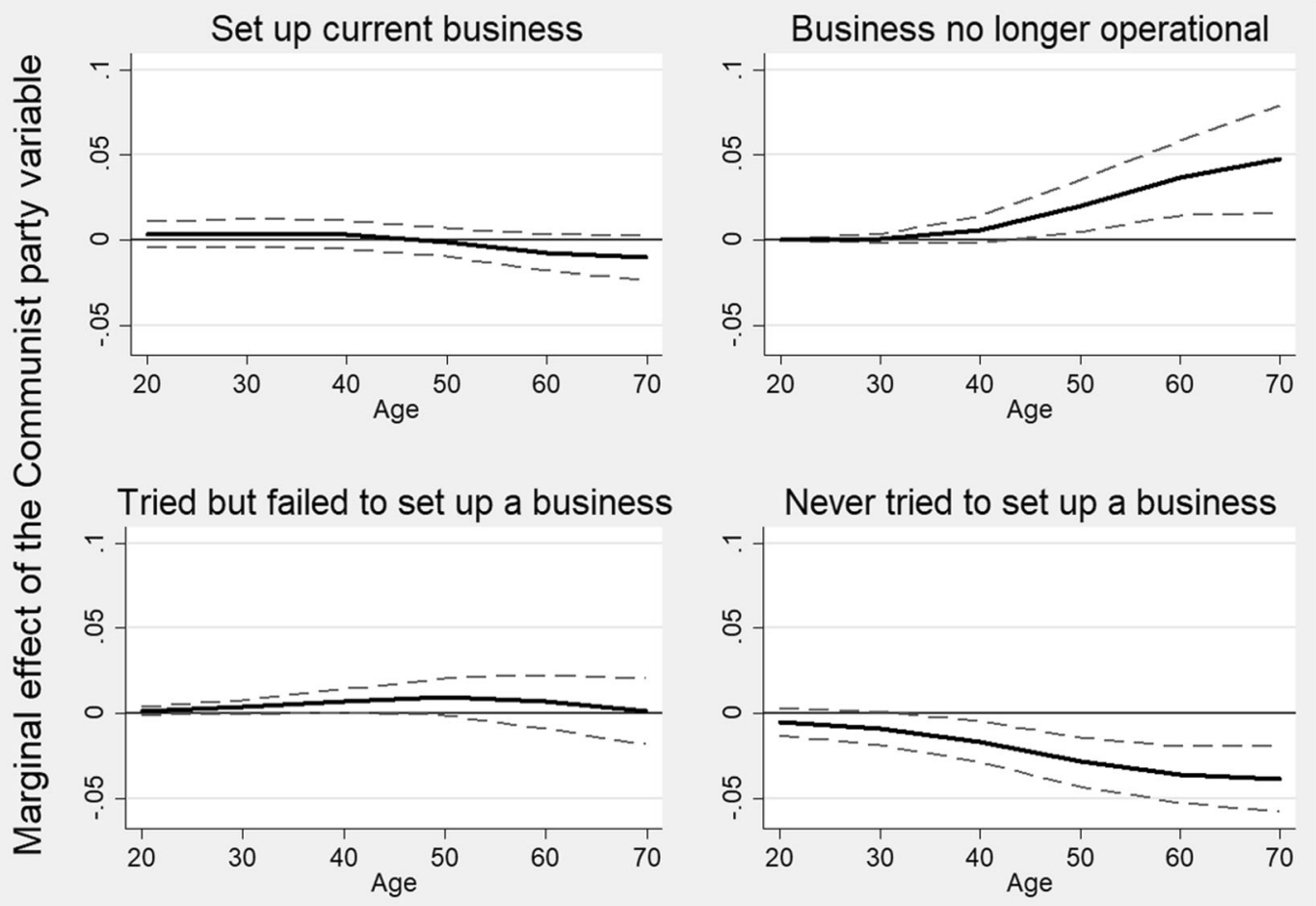

Fig. 3 Links to the former Communist party and entrepreneurial activity, by age, multinomial logit marginal effects. Notes: the graphs show multinomial logit marginal effects and their $95 \%$

confidence intervals calculated after estimating the baseline model (Table 3) with the interaction term between the links to the Communist party variable and age 
particular to the CEE. Nevertheless, these results represent associations between links to the former Communist party and present-day entrepreneurial activities and reflect, among other things, the causal effect of former party membership on present-day entrepreneurship as well as the self-selection into the party of people with specific characteristics that also affect the likelihood of undertaking entrepreneurial activities.

To disentangle the causal effect of party links from self-selection, we now turn to the control function results reported in Table 4. Both instruments capturing involvement in WWII are positive and individually significant at the $1 \%$ level in the first-stage regression (Column 1), indicating that being affected by WWII, or having a family member who was affected (either killed/ injured or displaced), strongly predicts links to the former Communist party. Instrument relevance is further confirmed by the F-test of excluded instruments, the value of which (206.57) exceeds the commonly accepted threshold value of $10 .^{12}$

The second-stage results (Columns 2-5 of Table 2) reveal statistically significant coefficients of the $1 \mathrm{st}$ stage residuals for all outcomes of the started business variable except having set up a current business, indicating that the Communist party variable is indeed endogenous. When we account for endogeneity, former Communist party ties increase the likelihood of having set up a business in the past but being no longer involved in it (or the business being non-operational) by 7.7 percentage points, having unsuccessfully tried to set up a business by 6.3 percentage points, and decrease the likelihood of having never tried to set up a business by 18.7 percentage points.

Concerning having set up and being involved in a current business (Column 2 of Table 4), a statistically insignificant estimate of the 1 st stage predicted residuals implies no endogeneity for this outcome and that the correlational result of Column 1 of Table 3 should be used. We thus conclude that former Communist party membership has no effect on having set up and currently running a business. Taken together, the results suggest that former Communist party ties were indeed instrumental in facilitating business set-ups. However, these political ties did not ensure that these businesses were on average more successful in the long term (25 years after the

\footnotetext{
$\overline{12}$ The full econometric output of the first stage results is available in Table S6.
}

regime change) or that the people who set them up would still be running them.

At the same time, the negative and statistically significant estimate of the first-stage residuals variable suggests that it is people with traits that make them less entrepreneurial who tended to self-select into the Communist party. Put differently, had the Communist party and the communist regime not existed, we would observe that these people, conditional on other control variables, were less - not more- likely to start businesses.

\subsection{Additional analyses}

This section explores whether the main relationships we identify depend on whether the connection to the former ruling party is personal or familial, and whether Communist connections matter less for the business outcomes of younger respondents. In additional analyses, we investigate whether beliefs about the nature of success and current political party membership mediate the main effects.

First, we split the Communist party variable according to whether the respondent was (1) him/ herself a former party member; (2) the child of a former party member; or (3) the relative of a former party member. The results of the correlational model, reported in Table 5, show that it is the former party members and their children who are driving the results ${ }^{13}$ : they are more likely (by 1.4 and 0.9 percentage points, respectively) to report that they set up a business in the past but are no longer involved in it, and less likely (by 3.1 and 1.2 percentage points, respectively) to report that they have never tried to set up a business. ${ }^{14}$

Furthermore, we explore whether connections to the former cadres are equally important along the age distribution by interacting the links to the former Communist party variable. ${ }^{15}$ Fig. 3 demonstrates that older respondents with former Communist party links are relatively more likely to have set up a business in the past that is no longer operational,

\footnotetext{
${ }^{13}$ Former Communist party members in our sample are on average 65 years old, compared to an average age of 53 years for the children of party cadres.

${ }^{14}$ We formally tested the difference in the coefficient estimates between the "Former Communist party member" and "Child of former Communist party member" variables and found that they are not statistically different from each other in any of the outcomes.

${ }^{15}$ See Supplementary Information Table S7 for econometric output.
} 
Set up current business

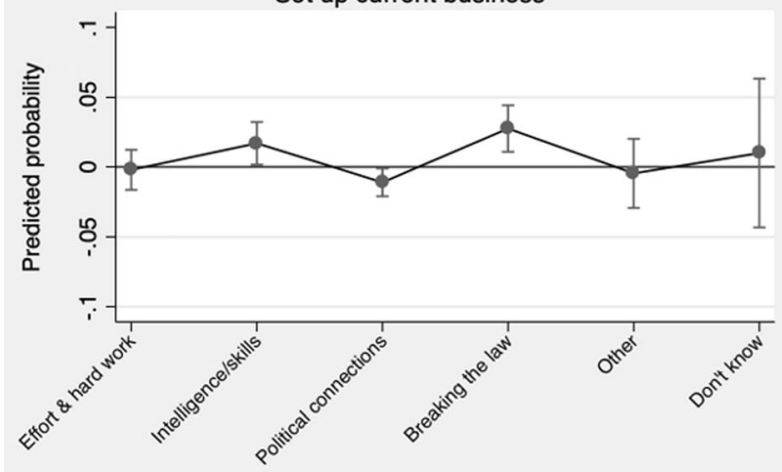

Tried but failed to set up a business

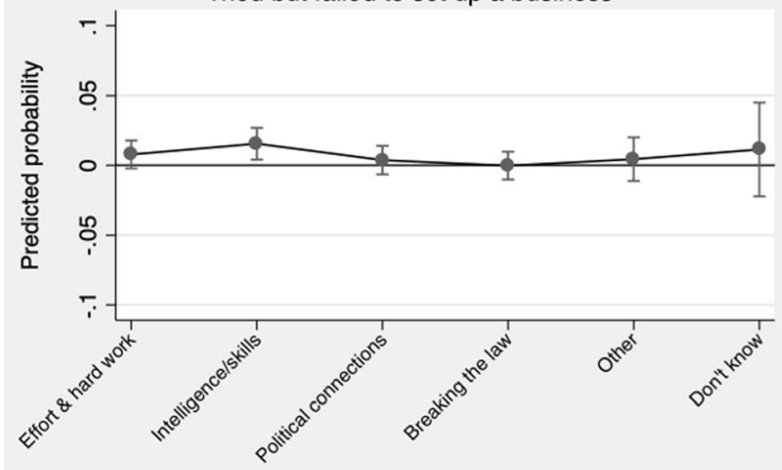

Fig. 4 Links to the former Communist party and entrepreneurial activity, by beliefs in factors to succeed in life, multinomial logit marginal effects. Notes: the graphs show multinomial logit marginal effects and their $95 \%$ confidence intervals calculated after

and less likely to say that they never tried to set up a business. Our results imply, therefore, that former ruling party ties are less important for the entrepreneurial outcomes of younger cohorts compared to their older counterparts.

Next, we investigate whether the relationship between former Communist party ties and present-day entrepreneurship depends on the individual values that people hold. To that end, we make use of a LiTS-III question about the most important factor to succeed in life, with possible answers including effort and hard work, intelligence and skills, political connections, and breaking the law. First, we find that people with former Communist party links are less likely to say that effort and skills are important and more likely to say that political connections and breaking the law matter for success, compared to

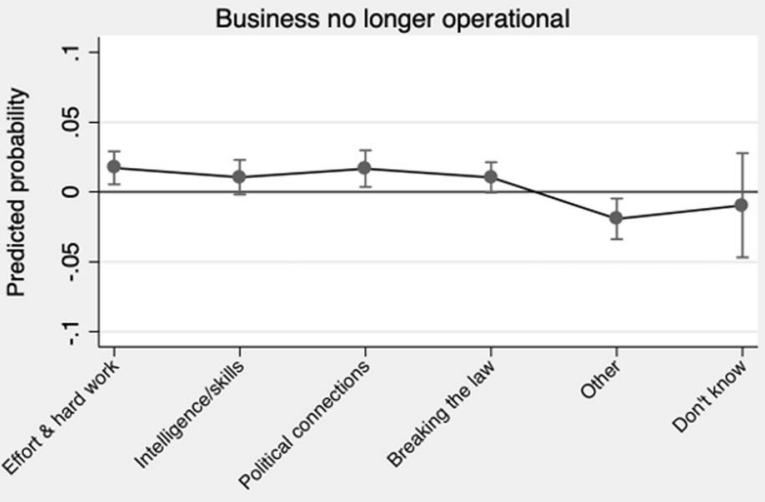

Never tried to set up a business

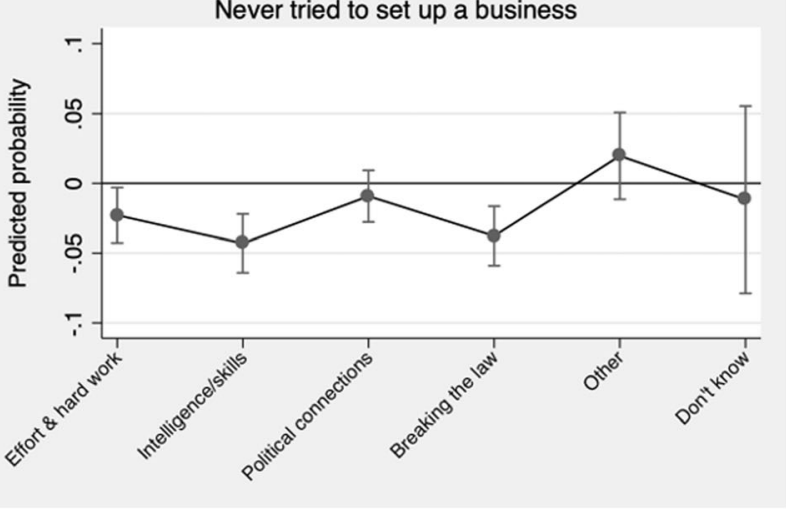

estimating the baseline model (Table 3) with the interaction term between the links to the Communist party variable and beliefs in factors to succeed in life

those without such ties (see Table S8 of Supplementary Information). ${ }^{16}$

We then complement the model in Eq. (1) with respondents' values related to success in life as well as the interactions between these factors and the Communist party variable. The results, reported in Fig. 4 and Supplementary Table S10 show that belief in political connections often underlies current entrepreneurial outcomes among former

\footnotetext{
${ }^{16}$ We have also checked if the value orientations of people with and without links to the former Communist party are different between workers in different industries. In these analyses, we consider all types of workers and not just entrepreneurs. The results, reported in Table S9 of the Supplementary Information, show that respondents with former party links who work in the construction, manufacturing, and services sectors are less likely to say that effort and hardwork are important to succeed in life than those working in the same industries but without such ties. Meanwhile, those with former Communist links working in the manufacturing sector are more likely to say that political connections are important.
} 

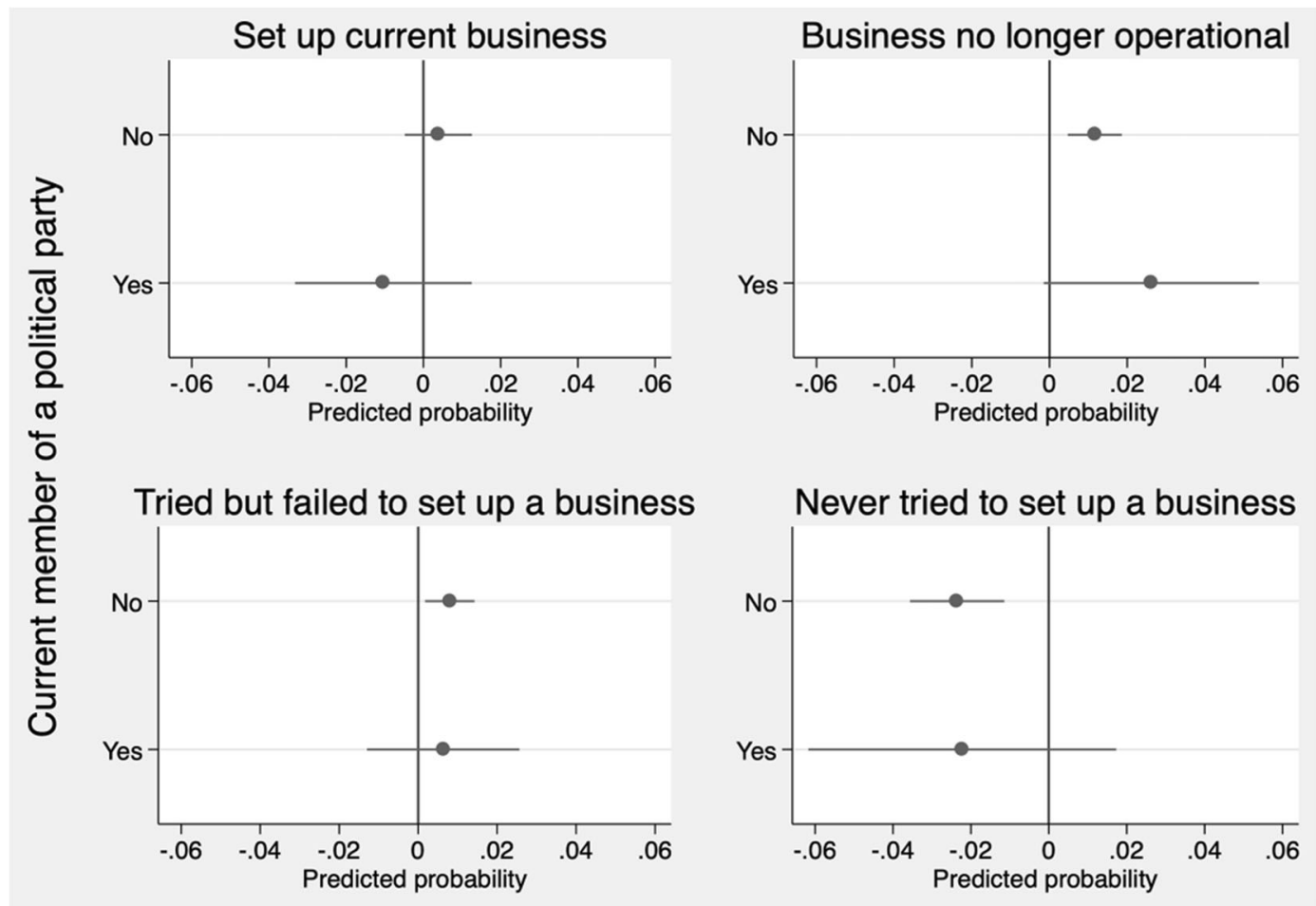

Fig. 5 Links to the former Communist party and entrepreneurial activity, by current membership of any political party, multinomial logit marginal effects. Notes: the graphs show multinomial logit marginal effects and their $95 \%$ confidence intervals calculated

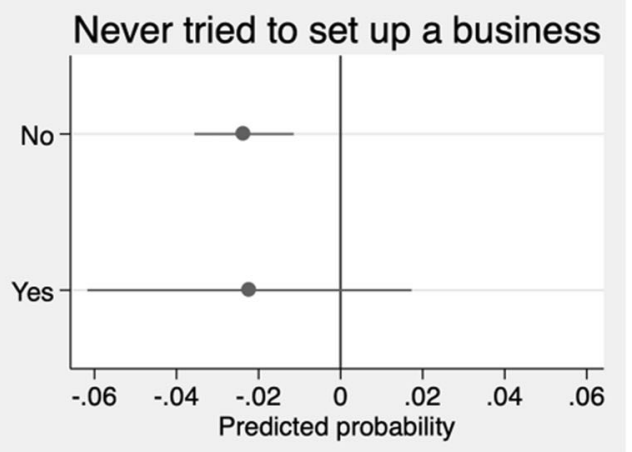

after estimating the baseline model (Table 3) with the interaction term between the links to the Communist party variable and current party membership of any political party

cadres. Specifically, people with former party links who believe that life success comes from intelligence and skills or by breaking the law are more likely to run a current business than former party members with other value orientations. Belief in personal effort and political connections among former party cadres are also associated with having a past business venture, which is no longer operational. Finally, former Communist party members who believe in intelligence and skills as a means to get ahead in life are more likely to have failed at setting up a business.

Finally, we explore whether current party connections amplify the power of former Communist connections in determining current entrepreneurial outcomes. Our baseline specification, reported in detail in Table S5, reveals that respondents who are current political party members are more likely to report running a current business, having set up a business that is no longer operational, and having tried but failed to set up a business. They are also less likely to say that they have never tried to set up a business. To investigate the possibility that past party connections transition to present ones, we add to our baseline model (Eq. 1) an interaction term between these two variables. The results, reported in Table S11 and Fig. 5 below, show that the main results we report do not depend on current political party affiliation. The coefficient estimates on the interaction terms in Table S11 are statistically not significant and the confidence intervals in Fig. 5 denoting the effect of the former Communist party on current entrepreneurship according to current political membership are overlapping. As such, these results imply that the social capital associated with links to the former Communist party is independent of current political party affiliations.

\section{Conclusion}

This paper is the first causal exploration of the long-term consequences of former Communist party ties for entrepreneurship in the post-socialist region. Our results demonstrate that the nature of entrepreneurship in CEE is path-dependent. Specifically, ties to the former ruling 
elites are instrumental for entrepreneurial start-up but not for entrepreneurial success. We also show that those with less favorable traits such as lower risk aversion, lower ability, or lower entrepreneurial aptitude, were in fact more likely to join the party. In subsequent analyses, we also show that people with former Communist party links believe that success depends on political connections and breaking the law rather than effort and skills. These findings raise questions about the moral dimensions of business practice in the region, and about whether the playing field has truly been leveled 25 years after the fall of the Communist regimes.

Our findings can be interpreted in one of two ways depending on whether former Communists and their children were pushed or pulled into entrepreneurship. On the one hand, the fact that the former Communist party allowed for a head start in entrepreneurial activity may suggest that the party had laid the foundations of inequality of opportunity in terms of entrepreneurship. On the other hand, our findings could be indicative of the fact that the least capable former Communist party members (or their children) became entrepreneurs and then subsequently closed down their businesses due to a lack of formal alternatives or discrimination in the labor market. In other words, these individuals may have been pushed into entrepreneurship out of necessity. In both cases, the fact that the former elites were negatively selected on traits such as ability and entrepreneurial aptitude, combined with the current low levels of entrepreneurship in the transition region, suggests that the negative consequences of communism for entrepreneurship were two-fold. First, communism had a longlasting damaging effect on entrepreneurship by encouraging a culture of state-reliance rather than self-initiative, which is inimical to free enterprise. Second, despite its focus on equality and egalitarianism, paradoxically, communism laid the foundations of unequal access to entrepreneurship by excluding those with resources and connections from starting a business, at least in the initial stages of democracy. From a social viewpoint, the fact that the least capable people attempted to start a business and subsequently failed while also crowding out people without elite connections may suggest a social welfare loss.

Our study also offers opportune avenues for future research, such as distinguishing the rank of the former party member (i.e., a party member vs. a party official) and unpacking the particular traits that made individuals or households more likely to become former party members but at the same time made them less entrepreneurial.

Acknowledgments We are thankful to two anonymous referees and the Associate Editor László Szerb, as well as Frank Fossen, Michael Wyrwich, Aard Groen, Olga Belousova, Andrew Austin, Ira N. Gang, and participants of the University of Groningen's Centre of Entrepreneurship Research Seminar for valuable comments and suggestions. Popova acknowledges the support from Russian Science Foundation grant No. 19-18-00262.

Open Access This article is licensed under a Creative Commons Attribution 4.0 International License, which permits use, sharing, adaptation, distribution and reproduction in any medium or format, as long as you give appropriate credit to the original author(s) and the source, provide a link to the Creative Commons licence, and indicate if changes were made. The images or other third party material in this article are included in the article's Creative Commons licence, unless indicated otherwise in a credit line to the material. If material is not included in the article's Creative Commons licence and your intended use is not permitted by statutory regulation or exceeds the permitted use, you will need to obtain permission directly from the copyright holder. To view a copy of this licence, visit http://creativecommons.org/licenses/by/4.0/.

\section{References}

Aidis, R., \& Adachi, Y. (2007). Russia: firm entry and survival barriers. Economic Systems, 31(4), 391-411. https://doi. org/10.1016/j.ecosys.2007.08.003.

Aidis, R., Estrin, S., \& Mickiewicz, T. (2008). Institutions and entrepreneurship development in Russia: a comparative perspective. Journal of Business Venturing, 23(6), 656-672. https://doi.org/10.1016/j.jbusvent.2008.01.005.

Alesina, A., \& Fuchs-Schündeln, N. (2007). Good-bye Lenin (or not?): the effect of communism on people's preferences. The American Economic Review, 97(4), 1507-1528. https://doi. org/10.1257/aer.97.4.1507.

Bateman, M. (2000). Neo-liberalism, SME development and the role of business support centres in the transition economies of Central and Eastern Europe. Small Business Economics, 14(4), 275-298. https://doi.org/10.1023/A:1008170805013.

Berkowitz, D., \& DeJong, D. N. (2005). Entrepreneurship and post-socialist growth. Oxford Bulletin of Economics and Statistics, 67(1), 25-46. https://doi.org/10.1111/j.14680084.2005.00108.x.

Block, J., Sandner, P., \& Spiegel, F. (2015). How do risk attitudes differ within the group of entrepreneurs? The role of motivation and procedural utility. Journal of Small Business Management, 53(1), 183-206. https://doi.org/10.1111 jjsbm. 12060.

Bollen, K. A., Guilkey, D. K., \& Mroz, T. A. (1995). Binary outcomes and endogenous explanatory variables: tests and 
solutions with an application to the demand for contraceptive use in Tunisia. Demography, 32(1), 111-131. https://doi. org/10.2307/2061900.

Brouthers, L. E., Lascu, D.-N., \& Werner, S. (2008). Competitive irrationality in transitional economies: are Communist managers less irrational? Journal of Business Ethics, 83, 397408. https://doi.org/10.1007/s10551-007-9627-6.

Caliendo, M., Fossen, F., \& Kritikos, A. S. (2014). Personality characteristics and the decisions to become and stay selfemployed. Small Business Economics, 42(4), 787-814. https://doi.org/10.1007/s11187-013-9514-8.

Campos, N. F., \& Coricelli, F. (2002). Growth in transition: what we know, what we don't, and what we should. Journal of Economic Literature, XL, 793-836. https://doi.org/10.1257 /002205102760273797.

Dallago, B. (2017). Diverging paths of entrepreneurship in transition countries: a comparative View. In A. Sauka \& A. Chepurenko (Eds.), Entrepreneurship in transition economies (pp. 423-444). Berlin: Springer.

Demirgüç-Kunt, A., Klapper, L., \& Panos, G. (2007). The origins of self-employment. Development Research Group (February). Washington DC: World Bank. Retrieved from http://siteresources.worldbank.org/INTFR/Resources/ BosniaFeb07Klapperetal.pdf

Djankov, S., Miguel, E., Qian, Y., Roland, G., \& Zhuravskaya, E. (2005). Who are Russia's entrepreneurs? Journal of the European Economic Association, 3(2-3), 587-597. https://doi.org/10.1162/jeea.2005.3.2-3.587.

Earle, J.S., \& Sakova, Z. (1999). Entrepreneurship from scratch: lessons on the entry decision into self-employment from transition economies. IZA Discussion Paper 79. Available at: http://ftp.iza.org/dp79.pdf

EBRD. (2016). 5. Annex: The survey and the sampling methodology. Retrieved from http://itsonline-ebrd.com/methodology-annex/

Estrin, S., \& Mickiewicz, T. (2011). Entrepreneurship in transition economies: the role of institutions and generational change. In M. Minniti (Ed.), The dynamics of entrepreneurship: evidence from the global entrepreneurship monitor data (pp. 181-208). Oxford, United Kingdom: Oxford University Press. https://doi.org/10.1093 /acprof:oso/9780199580866.003.0009.

Estrin, S., Meyer, K. E., \& Bytchkova, M. (2006). Entrepreneurship in transition economies. The Oxford handbook of entrepreneurship, 693-725. https://doi.org/10.1093 /oxfordhb/9780199546992.003.0027.

Estrin, S., Hanousek, J., Kocenda, E., \& Svejnar, J. (2009). The effects of privatization and ownership in transition countries. Journal of Economic Literature, 47(3), 699-728. https://doi. org/10.1257/jel.47.3.699.

Estrin, S., Mickiewicz, T., \& Stephan, U. (2013a). Entrepreneurship, social capital, and institutions: social and commercial entrepreneurship across nations. Entrepreneurship theory and practice, 37(3), 479-504. https://doi.org/10.1111/etap.12019.

Estrin, S., Korosteleva, J., \& Mickiewicz, T. (2013b). Which institutions encourage entrepreneurial growth aspirations? Journal of Business Venturing, 28(4), 564-580. https://doi. org/10.1016/j.jbusvent.2012.05.001.

Euractiv. (2002). Latvia bars candidates with a communist past from elections. Available at https://www.euractiv.com/ section/elections/opinion/latvia-bars-candidates-with-a-communist-past-from-elections/

Filatotchev, I., Starkey, K., \& Wright, M. (1994). The ethical challenge of management buy-outs as a form of privatisation in Central and Eastern Europe. Journal of Business Ethics, 13, 523-532. https://doi.org/10.1007/BF00881297.

Geishecker, I., \& Haisken-DeNew, J. P. (2004). Landing on all fours? Communist elites in post-Soviet Russia. Journal of Comparative Economics, 32(4), 700-719. https://doi. org/10.1016/j.jce.2004.08.007.

Gershenson, D., \& Grossman, H. I. (2001). Cooption and repression in the Soviet Union. Economics \& Politics, 13(1), 3147. https://doi.org/10.1111/1468-0343.00082.

Granovetter, M. (1985). Economic Action and Social Structure: The Problem of Embeddedness. American Journal of Sociology, 91(3), 481-510. https://doi.org/10.1086/228311.

Hamm, P., King, L. P., \& Stuckler, D. (2012). Mass privatization, state capacity, and economic growth in post-communist countries. American Sociological Review, 77(2), 295-324. https://doi.org/10.1177/0003122412441354.

Ivlevs, A., \& Hinks, T. (2018). Former communist party membership and bribery in the post-socialist countries. Journal of Comparative Economics, 46, 1411-1424. https://doi. org/10.1016/j.jce.2018.06.001.

Johnson, S., Kaufmann, D., Shleifer, A., Goldman, M., \& Weitzman, M. (1997). The unofficial economy in transition. Brookings Papers on Economic Activity, 1997(2), 159-239. https://doi.org/10.2307/2534688.

Karpov, M. (2017). Комсомол ответил «есть». Почему функционеры ВЛКСМ стали преуспевающими бизнесменами https://lenta.ru/articles/2017/06/11/ komsomol/

Kotz, D., \& Weir, F. (2007). Russia's path: from gorbachev to putin. The Demise of the Soviet System and the New Russia. London: Routledge.

Kritikos, A. S. (2014). Entrepreneurs and their impact on jobs and economic growth. IZA World Of Labor, 8, 1-10. https://doi. org/10.15185/izawol.8.

Ledeneva, A. V. (1998). Russia's economy of favors: blat, networking and informal exchange (Vol. 102). Cambridge University Press.

Lippmann, Q., \& Senik, C. (2018). Math, girls and socialism. Journal of Comparative Economics, 46(3), 874-888. https://doi.org/10.1016/j.jce.2018.07.013.

Long, J. S., \& Freese, J. (2014). Regression models for categorical dependent variables using Stata. Stata Press (3d ed.). College Station, TX: Stata Press.

Matthews, M. (2011). Privilege in the Soviet Union. A study of elite life-styles under communism. London: Routledge.

McMillan, J., \& Woodruff, C. (2002). The central role of entrepreneurs in transition economies. Journal of Economic Perspectives, 16(3), 153-170. https://doi.org/10.1257 /089533002760278767.

Neimanis, G. J. (1997). Business ethics in the former Soviet Union. Journal of Business Ethics, 16, 357-362. https://doi. org/10.1023/A:1017976419107.

Nikolova, M. (2019). Switching to self-employment can be good for your health. Journal of Business Venturing, 34(4), 664 691. https://doi.org/10.1016/j.jbusvent.2018.09.001.

Nikolova, E., \& Simroth, D. (2015). Religious diversity and entrepreneurship in transition: lessons for policymakers. 
IZA Journal of European Labor Studies, 4, 5. https://doi. org/10.1186/s40174-014-0028-4.

Nikolova, M., Popova, O., \& Otrachshenko, V. (2019). Stalin and the origins of mistrust. GLO Discussion Paper 344. Retrieved from https://www.econstor.eu/handle/10419/196129.

Nooteboom, B. (2007). Social capital, institutions and trust. Review of Social Economy, 65(1), 29-53. https://doi. org/10.1080/00346760601132154.

Ovaska, T., \& Sobel, R.S. (2005). Entrepreneurship in postsocialist economies. Journal of Private Enterprise, 21(1), 8-28. Available at: http://journal.apee.org/index.php/ Fall2005_2

Pakulski, J., Kullberg, J. S., \& Higley, J. (1996). The persistence of postcommunist elites. Journal of Democracy, 7(2), 133-147. https://doi.org/10.1353/jod.1996.0027.

Petrin, A., \& Train, K. (2010). A control function approach to endogeneity in consumer choice models. Journal of Marketing Research, 47(1), 3-13. https://doi.org/10.1509 /jmkr.47.1.3.

Rainer, H., \& Siedler, T. (2009). Does democracy foster trust? Journal of Comparative Economics, 37(2), 251-269. https://doi.org/10.1016/j.jce.2008.09.003.

Rivers, D., \& Vuong, Q. H. (1988). Limited information estimators and exogeneity tests for simultaneous probit models. Journal of Econometrics, 39(3), 347-366. https://doi. org/10.1016/0304-4076(88)90063-2.

Rona-Tas, A. (1994). The first shall be last? Entrepreneurship and Communist Cadres in the transition from Socialism. American Journal of Sociology, 100(1), 40-69. Retrieved from www.jstor.org/stable/2782537

Sauka, A., \& Chepurenko, A. (2017). Entrepreneurship in transition economies: diversity, trends, and perspectives: Springer.

Shapiro, M. (1991) Communist youth embrace capitalism. Washington Post https://www.washingtonpost.com/archive/politics/1991/10/20/communist-youth-embracecapitalism/1c878c85-cb22-4e13-b459-766a0c01b527/ ?utm_term $=.9 \mathrm{fda} 4295 \mathrm{~d} 39 \mathrm{a}$

Shelley, L. I. (1992). Entrepreneurship: some legal and social problems. In B. Dallago, G. Ajani, \& B. Grancelli (Eds.), Privatization and Entrepreneurship in Post-Socialist Countries. London: Palgrave Macmillan. https://doi. org/10.1007/978-1-349-12393-3 16.

Smallbone, D., \& Welter, F. (2001). The distinctiveness of entrepreneurship in transition economies. Small Business
Economics, 16(4), 249-262. https://doi.org/10.1023 /A:1011159216578.

Stoica, C. A. (2004). From good communists to even better capitalists? Entrepreneurial pathways in post-socialist Romania. East European Politics and Societies: and Cultures, 18(2), 236-277. https://doi.org/10.1177 /0888325403259864.

Szczerbiak, A. (2002). Dealing with the Communist past or the politics of the present? Lustration in Post-Communist Poland. Europe-Asia Studies, 54(4), 553-572. Retrieved from www.jstor.org/stable/826424

Szerb, L., \& Trumbull, W. N. (2016). The development of entrepreneurship in the European transition countries: is transition complete? Strategic Change, 25(2), 109-129. https://doi. org/10.1002/jsc.2051.

Terza, J. V., Basu, A., \& Rathouz, P. J. (2008). Two-stage residual inclusion estimation: addressing endogeneity in health econometric modeling. Journal of Health Economics, 27(3), 531-543. https://doi.org/10.1016/j. jhealeco.2007.09.009.

Tyson, L. D. A., Petrin, T., \& Rogers, H. (1994). Promoting entrepreneurship in Eastern Europe. Small Business Economics, 6(3), 165-184. https://doi.org/10.1007 /BF01108286.

van der Zwan, P., Verheul, I., \& Thurik, R. (2011). The entrepreneurial ladder in transition and non-transition economies. Entrepreneurship Research Journal, 1. https://doi. org/10.2202/2157-5665.1012.

van Praag, C. M., \& Versloot, P. H. (2007). What is the value of entrepreneurship? A review of recent research. Small Business Economics, 29(4), 351-382. https://doi. org/10.1007/s11187-007-9074-x.

Welsh, H. A. (1996). Dealing with the Communist past: Central and East European experiences after 1990. Europe-Asia Studies, 48(3), 413-428. Retrieved from https://www.jstor. org/stable/152734

Wooldridge, J. M. (2015). Control function methods in applied econometrics. Journal of Human Resources, 50(2), 420-445. https://doi.org/10.3368/jhr.50.2.420.

Publisher's note Springer Nature remains neutral with regard to jurisdictional claims in published maps and institutional affiliations. 